\title{
Supplementary protection certificates and their impact on access to medicines in Europe: case studies of sofosbuvir, trastuzumab and imatinib
}

\author{
Yuanqiong $\mathrm{Hu}^{1,2}$, Dimitri Eynikel ${ }^{3^{*}}$ (D, Pascale Boulet $^{4}$ and Gaelle Krikorian ${ }^{5}$
}

\begin{abstract}
In recent years, there has been increasing pressure on public health systems in high-income countries due to high medicines prices, one of the underlying causes of which are the market monopolies granted to pharmaceutical undertakings. These monopolies have been facilitated by expanded forms of intellectual property protections, including the extension of the exclusivity period after the expiration of the patent term concerning medicinal products. In the European Union such an approach lies in the Supplementary Protection Certificate, a mechanism formally introduced under Regulation 1768/92/EEC (now: Regulation 469/2009/EC, amended). After more than 20 years of implementation since it was first introduced, the common justifications for SPCs are being challenged by recent findings as to their functioning and impact. Similarly, legitimate questions have been voiced as to the negative impact of SPCs on timely access to affordable medicines.

On the basis of an analysis of three medicines for hepatitis $C$ and cancer treatments, the present article critically engages with the policy justifications underlying SPCs. It then analyses access challenges to a hepatitis $C$ medicine and an HIV treatment in Europe, highlighting the social cost of the introduction of SPCs. Both the normative and empirical analyses have demonstrated that the common justifications supporting the SPC regime are deeply questionable. The addition of SPC exclusivity has also heavily delayed competition and maintained high medicines prices in European countries. Ultimately, the granting of such extended exclusive private rights on medicines may result in unnecessary suffering and be a factor in the erosion of access to medicines for all.
\end{abstract}

Keywords: Access to medicines, Supplementation protection certificate (SPC), Drug prices, Intellectual property, Generic competition, European Union

\section{Background}

In the context of increasing financial pressure on health care systems within European countries, some European countries recently introduced treatment rationing (eg France, Switzerland) [1, 2]. Together, these developments increasingly threaten the sustainability of healthcare systems [3]. In 2016, the Council of the European Union (EU) invited the European Commission to provide an analysis on the EU pharmaceuticals incentives package [4]. Included in the review was the EU Supplementary

\footnotetext{
* Correspondence: dimitri.eynikel@msforg

${ }^{3}$ MSF Access Campaign, Médecins Sans Frontières, Rue de Lausanne 78, P. O Box 1016, CH-1211 Geneva 1, Switzerland

Full list of author information is available at the end of the article
}

Protection Certificate (SPC), a mechanism created in 1992 to provide additional marketing exclusivity following a given medicine's patent expiration.

A heated debate occurred throughout the review. The originator position firmly holds that extended market exclusivity is critical to securing growth and incentivising research and development (R\&D) [5]. This position is grounded in the notion that pharmaceutical development is a high-cost, high-risk, stringently-regulated process effectively resulting in a much shorter exclusivity period in the market than the 20-year patent term. The SPC system is hence argued to provide additional guarantee and incentive [6-9]. By contrast, the European generic industry argued that the SPC regime hindered 
their global competitiveness [10]. Answering generic undertakings' request for change, the Regulation was amended and Article 5 now allows generic production for export to third-countries ('manufacturing waiver') as a derogation and a 'storing' option permitting generic production 6 months pre-SPC expiration to prepare their products for market launch in the EU [11].

For their part, civil society organisations pointed to public health-related considerations, including the negative impact of SPC-extended market exclusivity on the affordability of medicines, whereby high prices are maintained which intensify concerns regarding the sustainability of medicines supply required for the treatment of all patients $[12,13]$. While the five studies commissioned and published by the Commission in 2017 and 2018 throughout the SPC review investigated the origin, practices, economic rationale, impact, and legal aspects of SPCs [14-18], they did not analyse the social impact of SPCs in depth from the perspective of securing and protecting the sustainable provision of health care to all patients in need. In light of these issues, key questions addressed in the present review include whether and to what extent SPCs and other pharmaceutical incentive measures strike the correct balance of interests and the extent to which SPCs may hinder the availability and affordability of lifesaving medicines in Europe.

In order to engage in an evidence-based discussion of the social impact of SPCs, this article begins with a brief overview of the development of patents and other market exclusivity instruments and their impact on access to medicines. Section two introduces the specific case of SPCs, including the recent Commission review, while section three assesses SPCs as a means of offsetting R\&D investments for selected medicines. The fourth section presents two recent cases of publicly-reported access to medicines challenges in a number of European countries. Finally, section five discusses the rationale and social cost of patent term extensions, such as SPCs, in light of the right to access medicines as an integral part of the realisation of the right to health for all.

\section{Methodology and scope}

To critically assess the impact of SPCs on access to medicines, a review of the existing literature and several case studies are presented. For the literature review, resources were obtained from public libraries (eg the British Library and the Institute of Advanced Legal Studies Library), websites, and online databases (eg Westlaw, HeinOnline, JSTOR, and LexisNexis). The assumption underpinning the SPC regime is that SPCs are necessary to provide a 'period of effective protection' 'sufficient to cover the investment put into the research' [19]. To test this presumption, sofosbuvir, trastuzumab, and imatinib were selected as case studies. These drugs were chosen for three main reasons: they all have high therapeutic value, are included in the World Health Organization (WHO) Model List of Essential Medicines, and have been made available at expensive prices whilst generating enormous revenues as 'blockbuster' medicines. For the three medicines, patent and SPC status, sales revenue, and R\&D investment were reviewed. Publicly available information was relied upon: sales revenue data is derived from originator supplier financial reports, and data on investments per product was found in literature, company reports and media outlets. To assess the social cost of high prices facilitated by market exclusivity, the cases of sofosbuvir and the fixed-dose combination tenofovir disoproxil fumarate and emtricitabine (TDF/FTC) are dissected, using a variety of public sources.

\section{Introduction: medicines pricing and SPCs}

To undergo a discussion and analysis of the impact of SPCs on access to medicines in Europe, it is imperative to comprehend the evolution of international law on pharmaceutical patents, a processes characterised by constant pressure for longer periods of exclusivity protection by the pharmaceutical industry [20]. Before 1992, a number of European countries did not provide patent protection on pharmaceutical products [21]. At the international level, the World Trade Organization (WTO) Agreement on Trade-Related Aspects of Intellectual Property Rights (TRIPS) entered into force in 1995 [20, 22]. Critics have convincingly argued that TRIPS was drafted by lawyers and economists in the interests of US-based corporations [23], illustrating the setting of a 'neo-liberal agenda of global governance' [20, 23]. Among other provisions, TRIPS unified the patent terms in different countries, requiring 20 years' patent protection from the date of filing (Article 33) [22]. Consequently, TRIPS extended patent terms under most national laws, which previously had often ranged from 15 to 17 years, although in some cases they could be as short as 5-7 years [24]. Despite the extended protection period, pharmaceutical sector lobbying persisted seeking even longer exclusivity by resorting to various legal and regulatory means, including patent term extensions or restorations.

At the domestic level, one of the most influential examples in the early shift towards the extension of pharmaceutical patent terms was the US Drug Price Competition and Patent Term Restoration Act 1984, often known as the Hatch-Waxman Act [25]. This Act provided an extension of the patent term of up to 5 years, thus enabling up to 14 years of an effective statutory monopoly as of the marketing date [26]. The Hatch-Waxman Act had farreaching effects, particularly the legislative reasoning for granting this extended exclusivity - ie to compensate for marketing time lost fulfilling regulatory requirements and to recover $R \& D$ investments [26, 27]. In the 1990s in Europe, several countries adopted similar legislation that 
extended pharmaceutical market exclusivity status upon patent expiry in the form of SPCs, eg in France and Italy $[28,29]$. To preserve the integrity and the functioning of the common market, the European Economic Community established a uniform system for granting SPCs in 1992 [19]. SPCs are not, however, the only EU mechanisms offering protection beyond patent expiry; other types not dealt with in this study include the paediatric extension, orphan market exclusivity, data exclusivity, and market protection. Such additional protections go beyond the obligations imposed by TRIPS and are hence typically referred to as 'TRIPS-plus' provisions. The EU systematically tries to impose SPC-type provisions in other countries via bilateral trade negotiations.

Many such TRIPS-plus provisions have proven detrimental to accessing affordable medicines in Europe [30] and elsewhere [31]. For instance, a study on the public health impact of introducing patent term extensions in Thailand found that a five-year market exclusivity extension would result in an annual increase in medicines expenditure from USD 146.3 to 696.4 million [32]. Similarly, a study on existing Australian patent term extensions demonstrated that their elimination could save up to AU \$241 million per year on public pharmaceutical expenditure [33]. Following the 2017 conclusion of the Canada-EU Comprehensive Economic and Trade Agreement (CETA) and the consequent adoption of an up to 2 years' 'certificate of supplementary protection' (CSP) following patent expiry [34], a retrospective Canadian Parliament study estimated the CSP regime would have led to an increase in annual medicines expenditure of CA $\$ 392$ million ( $€ 260$ million) if it had been adopted 2 years earlier [35]. The latter examples concern highincome countries with largely similar market structures to those found in Europe, serving as appropriate comparisons for the purposes of our discussion and analysis of the actual cost of introducing market exclusivity mechanisms.

\section{SPCs in the European Union}

An SPC is a special intellectual property (IP) right (title) available for medicinal products, including chemical pharmaceutical products and biological medicines that require authorisation by national regulatory authorities before they can be marketed. SPCs are granted by national patent offices (NPOs) based on the SPC Regulation [36]. The conditions for the grant of an SPC are outlined in the Regulation, requiring inter alia that the SPC be requested within 6 months of the medicine's first market authorisation (Article 7(1)), which is protected by a 'basic patent in force' (Article 3(a)), or within 6 months from the grant of the patent if this occurred after the market authorisation was awarded (Article $7(2))$. In addition, the product must not have already been the subject of an SPC (Article 3(c)). If these conditions are satisfied, the SPC shall take effect at the end of the 20-year term of the basic patent for a period equal to the period which elapsed between the filing date of the basic patent and the date of the first market authorisation of the medicine, reduced by a period of 5 years (Article 13).

Strictly defined, an SPC is not a patent term extension, as that would require amending EU Member State national patent laws and the European Patent Convention; nevertheless, the effects of SPC-derived exclusivities are identical to those derived from patents. In other words, SPCs de facto enable right-holders to maintain monopoly prices and effectively function identically to a patent extension or restoration. The rationale for introducing this extension scheme is to make up for exclusivity time lost between patent registration and marketing authorisation, since the former usually occurs several years before the latter [15]. Some argue that this time needs to be restored to ensure sufficient return on costly pharmaceutical R\&D expenditures [37].

In 1992, the SPC Regulation, as codified in 2009, created a scheme for medicinal products 'to provide adequate effective protection' and reduce 'the risk of research centres ... relocating to countries that already offer greater protection' [19]. To have 'adequate effective protection' under the Regulation, 'the holder of both a patent and a certificate should be able to enjoy an overall maximum of fifteen years of exclusivity' from the marketing authorisation [19]. The Regulation assumed that otherwise, 'the period of effective protection under the patent [was] insufficient to cover the investment put into the research' [19]. Between 2010 and 2016, 86\% of new medicines introduced had an SPC in at least one country, and SPC protections have been filed on average in 18-19 Member States [18]. Meanwhile, concerns surrounding pharmaceutical expenditure and the corresponding threat to healthcare systems' sustainability have grown, with medicines constituting $17.1 \%$ of the total health expenditure in the EU and $1.41 \%$ of GDP in 2014 [38]; moreover, new medicines spending outpaces growth in GDP and other healthcare expenditures [39]. In addition, the Commission acknowledges that 'public and private payers increasingly grapple with how to afford the rising number of new and often expensive medicines' [3]. In June 2016 the Council of the EU under the Dutch presidency expressed 'concern about examples of a market failure...where patients access to effective and affordable essential medicines is endangered by very high and unsustainable price levels' and concluded 'that the incentives in this specific legislation need to be proportionate to the goal of encouraging innovation, improving patients' access to innovative medicines with therapeutic added value and budgetary impact' [4]. Accordingly, the 
Council requested the Commission undergo an evidence-based analysis of the impact of some current incentive mechanisms - including SPCs - on innovation, availability, and accessibility of medicinal products [4]; two of the studies procured by the Commission and published in May 2018 specifically investigated the economic impact and legal aspects of SPCs $[14,15]$.

Of the studies procured by the Commission, that by Copenhagen Economics (CE) provides an extensive overview of the functioning, use, and impact of the various IP incentives in Europe, including SPCs [15]. The study by the Max Planck Institute (MPI) examines the functioning of the SPC system from a legal perspective [14]. The latter study points to significant divergence between the CJEU's interpretation of the SPC Regulation and NPO practice, and also between current practice and the original intentions and limitations in respect to SPCs. The study therefore calls for greater coherence in the granting of SPCs, a finding echoed by a Technopolis report requested by the Dutch government [40]. The Commission has advanced the idea of a unitary SPC title at the EU level, in place of national SPCs, in accordance with the new unitary patent system of the European Patent Office [41].

On a number of critical issues, however, the studies reached different conclusions. CE presents a positive corelation with the average effective protection period in countries of export and domestic pharmaceutical R\&D spending [15], while the MPI study reasoned that an increase in innovation after the introduction of SPCs 'does not imply a cause-effect relationship with the enactment or the amendment of that specific regulation' [14]. The Technopolis study could not confirm the incentivising effect of SPCs since the factors driving pharmaceutical $R \& D$ expenditure could not be identified, also noting that the SPC regulation 'does not contain any provisions to favour innovation originating from Europe over that from elsewhere' [40]. The latter report also points to alternative incentives such as prizes and conditional investments in basic research as effective means to spur innovation.

Additionally, the MPI study questions whether the availability of patent or SPC protection affects companies' decisions to locate research facilities in one jurisdiction or another, emphasising that other factors are likely of greater importance [14]. Only CE argues that SPCs could play a role in attracting innovation to Europe, while conceding that taxation, education, and other factors are probably more significant in that respect [15].

The Technopolis case studies into atorvastatin, omeprazole, and losartan estimated the total cost of SPCs to the Dutch healthcare system to be between $€ 120-660$ million for each medicine [40]. The MPI and CE studies both note that the SPC-induced generic entry delay may negatively impact healthcare budgets $[14,15]$. The CE study estimated that shifting $10 \%$ of total spending from originator to corresponding generic products would generate a saving of USD 12.4 billion ( $€ 11$ billion), ie $1 \%$ of the EU healthcare spending [14].

Combined, the three studies demonstrate the degree of inconclusiveness surrounding the SPC regime's impact as an innovation incentive and limited (or nonexistent) influence in attracting R\&D activities to Europe. Absent from the existing reviews of the EU SPC system, however, are two elements: (1) whether companies objectively need SPCs to recover R\&D investments and (2) an assessment of the social cost of the SPC Regulation, further developed below.

\section{SPCs: a fair mechanism to recover R\&D investments?}

This section critically assesses the grounds and regulatory objectives advanced to justify granting additional exclusivity rights, whether SPCs are necessary to recover R\&D costs, and whether without SPCs the much-needed R\&D on medicinal products would not be undertaken within the EU.

The claim that $R \& D$ investments cannot be recovered without extended exclusivity is frequently relied upon when SPCs or patent term extensions more generally are discussed, but supporting evidence remains scant. The key question is whether the patent holder cannot generate sufficient sales revenue to match or surpass the $R \& D$ investment from market approval to patent expiry, and hence whether an exclusivity extension to prevent generic competition should be implemented to do so. This hence calls for R\&D investment calculations and investigating whether the 20-year patent term is indeed too short to serve its intended purpose.

Defining the R\&D investment for a particular medicine is hampered by a lack transparency in pharmaceutical markets, particularly as to cost and R\&D investment information for individual products. There is an ongoing debate related to $R \& D$ costs $[42,43]$, with estimates for the cost of bringing a new product to the market ranging from USD 320 million to 2.7 billion (adjusted for 2017 USD) [44]. An important factor in this context is what exactly constitutes an individual product's $R \& D$ 'cost', which could arguably be limited to expenses directly linked to developing the individual medicine. Yet, industry and certain scholars argue that the cost of failures and opportunity costs should also be included, leading to much higher figures [42, 45]. A 2017 analysis of ten companies and drugs by Prasad and Mailankody [44], however, found the median cost of developing a new cancer medicine was USD 648 million, including failures; when opportunity costs were added, the median cost was USD 793.6 million [46]. The authors also found 
that $90 \%$ of the medicines' sales revenues had surpassed R\&D spending a median of 4 years after market approval (ranging from $0.8-8.8$ years), and $80 \%$ when failure and opportunity costs were included [44].

In the absence of exact $R \& D$ expenditure data from pharmaceutical companies on the three medicines selected for this study, publicly available information is used to establish proxy indicators for the amount of investment required to bring a product to market. It was not possible to verify whether the cited figures include failure or opportunity costs.

For Solvadi ${ }^{\oplus}$, Herceptin ${ }^{\bullet}$, Gleevec/Glivec ${ }^{\circ}$ sales revenues are compared with companies' claimed R\&D investments and the length of time for which the product was marketed. Table 1 provides an overview of originator companies' annual sales of three highpriced drugs over the past 14 years. It should also be noted that, while Gleevec ${ }^{\bullet}$ was first marketed in 2001, differing data exists for the first 3 years' sales revenue; for accuracy, this study therefore only focuses on data from 2004 onward.

\section{Sofosbuvir and Gilead}

Sofosbuvir, a highly effective direct-acting antiviral (DAA) medicine for treating hepatitis $\mathrm{C}$ infections, was first marketed by Gilead as Sovaldi and is one of the most expensive pharmaceutical products in the US

Table 1 Reported global annual product sales by calendar year for selected medicines according to company annual reports (2004-2017) (in million USD) ${ }^{a}$

\begin{tabular}{llll}
\hline Year & $\begin{array}{l}\text { Sovaldi }^{\oplus} \\
\text { (sofosbuvir) } \\
\text { Gilead [47] }\end{array}$ & $\begin{array}{l}\text { Herceptin }^{\oplus} \\
\text { (trastuzumab) }_{\text {Roche \& Genentech [48] }}\end{array}$ & $\begin{array}{l}\text { Gleevec/Glivec }^{\oplus} \\
\text { (imatinib) } \\
\text { Novartis [49] }\end{array}$ \\
\hline 2004 & N/A & 1162 & 1634 \\
2005 & N/A & 1717 & 2170 \\
2006 & N/A & 3142 & 2554 \\
2007 & N/A & 4027 & 3050 \\
2008 & N/A & 4736 & 3944 \\
2009 & N/A & 4845 & 3944 \\
2010 & N/A & 5212 & 4265 \\
2011 & N/A & 5936 & 4659 \\
2012 & N/A & 6301 & 4675 \\
2013 & 139 & 6565 & 4693 \\
2014 & 10,283 & 6840 & 1237 \\
2015 & 5276 & 6800 & 1219 \\
2016 & 4001 & 6918 & 3323 \\
2017 & 964 & 7154 & 1943 \\
Total & 20,663 & 34,277 & 43,310 \\
\hline
\end{tabular}

${ }^{a}$ Amounts rounded to millions. Trastuzumab sales have been converted from CHF to USD using historical exchange rates
[50]. Just 1 year after launch, in 2014 Gilead reported USD 10.3 billion in global sales of this product [47], and over USD 20 billion from 2014 to 2017, as indicated in Table 1. Gilead's actual R\&D investment in sofosbuvir is unknown, though it acquired sofosbuvir through a USD 11 billion acquisition of Pharmasset in 2011 when Phase III trials on sofosbuvir were nearing completion [51]. The medicine was approved by the US Food and Drug Administration (USFDA) in December 2013 [52], and by the European Medicines Agency (EMA) in January 2014 [53]. Within the first 3 years after market launch, Gilead's sales revenue for sofosbuvir surpassed the cost of the Pharmasset acquisition, and in just 5 years the sales revenue was almost double this investment.

In Europe, Gilead was granted a patent on sofosbuvir prodrug by the European Patent Office (EPO) [54], due to expire in 2028, in addition to a patent on the base compound [55]. Some Member State NPOs also granted Gilead SPCs that expire in 2029 [56-59]. Whether Gilead in fact needs an additional 9 months exclusivity to recover its sofosbuvir-related investment is doubtful: within 5 years of market approval (and long before the primary patent expiration) sofosbuvir sales revenues are nearly double the company's disclosed investments in the Pharmasset acquisition.

\section{Imatinib and Novartis}

The second example concerns the R\&D investment-SPC relationship for imatinib, sold by Novartis as Gleevec ${ }^{\circ}$ or Glivec $^{\circ}$ (depending on the country). When the drug was first approved in 2001, the price was set around USD 30, 000 for a years' supply. With an expected annual sales revenue of USD 900 million for imatinib in the US alone, the company would have been able to retrieve imatinib R\&D investments within the drug's first 2 years on the market [60]. Novartis allegedly aimed for this price, since the potential life-prolonging benefit remained uncertain [61]. However, as the medicinal benefit of the drug became clear the company increased its price, which reached USD 92,000 per year in 2012 in the US [61]. This increase was publicly denounced by more than 100 experts, including scientists involved in imatinib's discovery [61]. According to company reports (Table 1), imatinib generated over USD 43 billion globally from 2004 to 2017 .

Novartis was granted a patent by the EPO on the basis compound of imatinib, which expired in 2013 [62]. In addition, Novartis secured an SPC which expired in 2016 (eg in the Netherlands [63] and France [64]). As the sales revenue from the first 2 years after the launch of imatinib (ie 2001 and 2002), not included in the table above, were expected to suffice 
to recover the R\&D investment, it is unlikely Novartis actually needed three additional years of market exclusivity in order to cover its R\&D investment.

\section{Trastuzumab and Roche}

The third example relates to trastuzumab, a drug sold by Roche as Herceptin ${ }^{\circ}$ for the treatment of breast cancer developed by Genentech. In 1998 the drug successfully passed Phase III clinical trials and was undergoing fast-tracked USFDA approval when Genentech signed a licensing agreement in which Roche obtained all rights to license the drug outside the US [65]. The agreement stipulated that Roche was to pay a USD 40 million upfront fee with cash milestones for product development activities, that global development costs were shared, and that Genentech was to receive royalty payments [66]. In 1999 when trastuzumab entered the market, a sales revenue of CHF 300 million [67], roughly USD 200 million at the historical exchange rate [68] and equivalent to five times Roche's upfront investment of USD 40 million was reported for the medicine. Between 2004 and 2017, trastuzumab sales accumulated to USD 34 billion (Table 1).

In Europe, Roche secured patent protection for trastuzumab, which expired in 2012 [69]; several countries granted SPCs extending exclusivity a further 2 years [70-72]. The full details of Roche's investment to acquire the trastuzumab licence are undisclosed, though it appears to have been part of an extended arrangement [67] which ultimately led to Genentech's acquisition by Roche in 2009 [73]. While acknowledging these limitations, the idea that a two-year SPC was necessary to recover trastuzumab investment costs becomes questionable when sales exceeded five times the upfront investment to acquire the licence for trastuzumab in the first year it was marketed.

Table 2 Key dates and relevant protection periods for sofosbuvir, imatinib, and trastuzumab, based on SPCs granted in France $[56,64,71]$

\begin{tabular}{llll}
\hline Product & Sofosbuvir & Imatinib & Trastuzumab \\
\hline Year of market launch & 2013 & 2001 & 1999 \\
$\begin{array}{l}\text { Year sales revenue surpassed } \\
\text { R\&D investment }\end{array}$ & 2015 & 2003 & 2000 \\
Basic patent expiry date & $26 / 03 /$ & $25 / 03 / 2013$ & $15 / 06 / 2012$ \\
& 2028 & & \\
SPC term & $>9$ & $>3$ years 8 & > 2 years 1 \\
& months & months & $\begin{array}{l}\text { month } \\
\text { SPC expiry date }\end{array}$ \\
& $17 / 01 /$ & $21 / 12 / 2016$ & $29 / 07 / 2014$ \\
\hline
\end{tabular}

Based on the available data, the justification for SPCs that patent protection periods are insufficient to cover R\&D investments [19] appears deeply flawed for all three medicines investigated. In each case, the sales revenues surpassed the companies' R\&D investments within 3 years after market launch and more than 10 years before the end of the basic patent term. The TRIPS-agreed 20year patent term would have been more than sufficient to recover the relevant $R \& D$ investment, proving that the assumed general need for SPCs is incorrect for some (and potentially more) medicines. These findings also strongly challenge the relevance of temporal considerations in the SPC approval process. Costs are the only relevant factor in whether a company has been able to off-set its investment to develop or acquire a medicine, requiring precise details on the cost structure of a medicine's development and a company's own investments.

\section{High drug prices eroding access to medicines}

Ensuring access to all medicines by patients in need is a core human right obligation of the states in light of the right of health [74]. Multiple factors impede access to medicines, price being one of crucial prominence, as highlighted by a recent UN report [75]. Whereas prices that are 'too low' have resulted in the limitation or cessation of product supply, prices that are 'too high' have impeded the ability of healthcare systems to ensure medicines availability for all patients [76]. In May 2017, the WHO-Dutch government Fair Pricing Forum indicated that drug pricing has become a global issue, even affecting the wealthiest of countries [77]. While many factors hamper access to medicines in Europe (eg manufacturing quality issues or regulatory delays) the case studies below highlight how product price (enabled by patent or SPC market exclusivity) serves as a barrier to treatment and how medicines prices have threatened healthcare systems' sustainability. While the first case study, sofosbuvir, is a fairly newer medicine, the second, TDF/FTC, is nearing the end of its market exclusivity meaning SPC considerations are especially relevant.

\section{Sofosbuvir}

The highly-effective hepatitis $\mathrm{C}$ treatment sofosbuvir, discussed above, is marketed at high prices that severely financially burden health systems globally, including in European countries [78]. This results in patients being denied treatment access. In France, the total cost of sofosbuvir-based treatments was estimated to be $20 \%$ of total medicines expenditure in 2014 [79], which 'put at risk on the medium term the sustainability of the health care system' [80]. The government subsequently restricted treatment provision in 2015 to adults with the most severe conditions [79]. In 2016 these restrictions 
were formally lifted [81]. With an estimated 130,000 hepatitis $C$ patients and treatment costing $€ 28,000$ per patient or more $[82,83]$, the cost of DAAs continues to debilitate the French health system. In Romania, approximately five hundred thousand to one million people are infected with hepatitis $\mathrm{C}$, the highest burden in Europe, yet treatment was limited to 5800 patients from 2015 to 2016 [84]. In Italy, which also faces a heavy hepatitis C burden, in 2017 the Ministry of Health agreed to allow the personal use of unregistered generic medicines because the healthcare system could not afford treatment for all patients [85]. In Ireland, the 2017 budget of $€ 30$ million for the country's hepatitis C programme was effectively spent halfway through the year, forcing authorities to deny newly-registered patients treatment [86]. Meanwhile, generic versions of key $D A A s$, including sofosbuvir, have become available on the global market, leading to generic competition and much lower prices [87]; the patent as granted is also under post-grant oppositions launched by civil society organisations and other actors [88]. Médecins Sans Frontières (MSF) announced at the end of 2018 that it has obtained generic hepatitis $C$ treatments at a cost of $€ 75$ for a 12-week course [89].

Unless TRIPS flexibilities as voluntary or non-voluntary licences are considered and implemented, Gilead's monopoly remains in effect in Europe until 2029, enabling the company to charge high prices beyond the expiry of the original patent in 2028. While the sofosbuvir SPC does not cause the documented access challenges it certainly appears contentious to grant such a certificate that will further prevent generic competition, given that sofosbuvir sales revenue surpassed Gilead's R\&D investment approximately 2 years after market entry.

\section{TDF/FTC}

TDF/FTC, first marketed by Gilead as Truvada ${ }^{\circ}$, has long been used as an effective anti-retroviral medicine for treating HIV/AIDS; it has been recommended by the WHO to be used as a PrEP to protect at-risk individuals from contracting HIV [90]. TDF/FTC is a combination of tenofovir [91] and emtricitabine, both of which were developed by Gilead [92]. Gilead applied for SPCs for TDF/FTC in many European countries, which were due to expire in 2020 [93].

However, Gilead's SPC was revoked in France and Germany [94, 95]. The SPC was also rejected in the Netherlands [96], as was a preliminary injunction request by Gilead to prevent generic competition in Ireland [97, 98]. In other countries, such as Denmark [99] and Switzerland, $[100,101]$ the SPC has been maintained. In Belgium, a court ruled in favour of Gilead [102]. These divergences in application of the SPC Regulation stemmed from uncertainties related to the definition of the condition of having a 'basic patent in force' to obtain an SPC, a question finally referred to the Court of Justice by the UK High Court in Teva and others $v$ Gilead [103, 104].

In 2016, a European Centre for Disease Prevention and Control (ECDC) survey revealed that 31/32 European countries identified the cost of drugs as an issue preventing or limiting PrEP availability, and 24 rated the issue of high importance [105]. With no generic version available on the market at that time, the price of Truvada $^{\circ}$ was thus considered the main access barrier to the prophylaxis. As of October 2017, several generic versions of TDF/FTC had been EMA-approved [106] though they were not marketed in all Member States due to the effects of the associated SPCs. On 25 July 2018, the CJEU referred the case back to national courts signalling that the SPC should be revoked. Table 2 below shows the fragmentary availability of generic forms of TDF/FTC on the European market just prior to the ECJ decision.

The SPC status for TDF/FTC in different countries is indicated in Table 3, which also lists the prices of Truvada $^{\circ}$ and the cheapest generic forms according to the available information. As standardised pricing information is not available across Europe, the available pricing information differs greatly between countries. Pricing information in Table 3 should thus only be used to demonstrate the price differences between generic and originator versions within the same country. The table also details the availability of generics and whether TDF/FTC for PrEP was reimbursed in a country as of 23 July 2018.

Where the SPC was rejected or revoked, affordable generic forms of TDF/FTC have become available, eg in Ireland, France and the Netherlands. Other than Belgium, none of the countries where the SPC was maintained reimburse PrEP. While no comprehensive data is available on the use of PrEP in the listed countries in function of the price, it can be reasonably assumed that few people can afford out-of-pocket expenses of $€ 400$ or more for monthly treatment. These high prices, combined with the lack of reimbursement, have compelled individuals to resort to internet purchases for generic alternatives [131]. In England, a generic version of the drug for PrEP use is only available as part of a clinical trial which has enrolled 10,000 people $[125,126]$. However, as demand surpassed availability, the NHS started to facilitate importation, and sales of generics commenced in a London clinic earlier this year [132]. It is worth noting that generic TDF/FTC has been available on the global market for more than 10 years.

Overall, this analysis demonstrates that the Truvada decision can enable widespread access to generic versions of TDF/FTC in Europe [106]. With generic prices 53-94\% lower in countries where available, the case may have a profound impact on the affordability of a PrEP programme, the reimbursement status of TDF/FTC as 


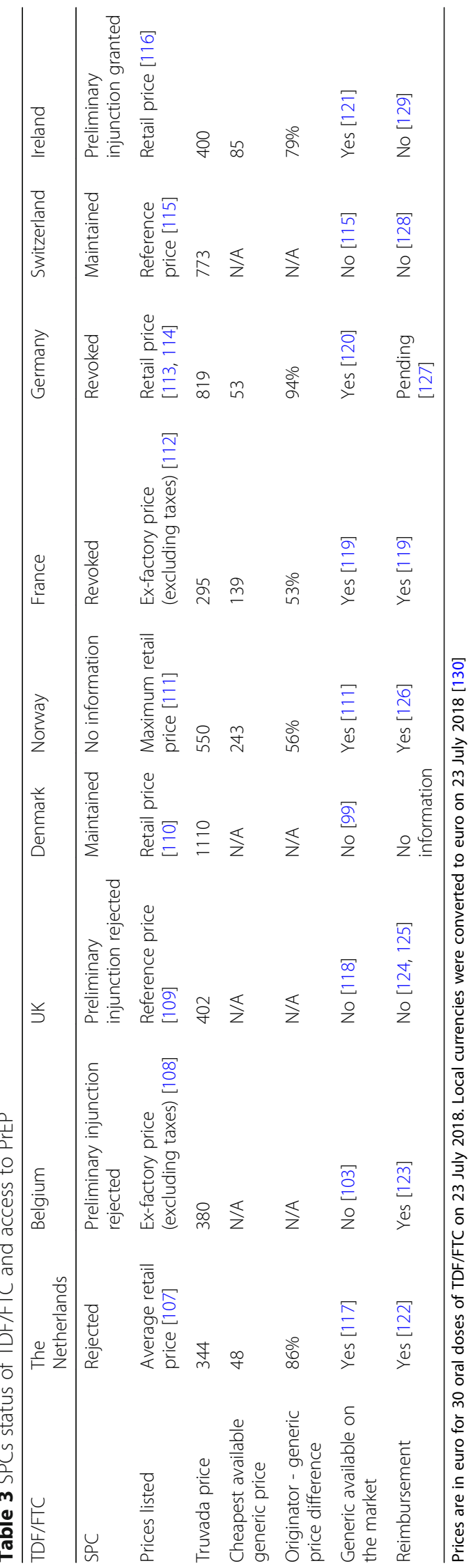


PrEP, and on the ability of users to pay for their own medicine.

\section{The social cost of SPCs}

SPCs can also come at a 'social cost'. While the concept of social costs is still matter of debate, it was described by $\mathrm{K}$ William Kapp as the economic problem of 'tangible and intangible damages and losses caused by economic activities ... not accounted for in the cost accounts of those responsible for their production, but are shifted to and borne by third persons, the whole community or future generations' [133]. Kapp later enlarged the notion to include all damages and harmful effects of private and public decision-making if they are the result of the pursuit of a private gain [133]. In recent years, the factoring of social cost gained relevance in the context of eg environmental issues [134], but is also mentioned in respect to obstruction to competition through information hoarding via trade secrets claims [135]. As illustrated in Section four above, high medicines prices constrain the optimal use of state resources and compel states to resort to treatment rationing, undermining the enjoyment of the patient's right to health. Besides individuals being denied treatment, potentially causing unnecessary suffering or death, the social cost of SPCs could be expressed as an opportunity cost, ie the impeded ability of healthcare systems to invest in other medicines, commodities, healthcare services, or quality of care. While outside the scope of this study, the extended social cost of SPCs appears particularly relevant for further research and policy considerations.

While SPCs are intended as innovation incentives, they can hinder the availability and affordability of lifesaving medicines. It therefore appears that this tool does not reflect the balance of interests originally intended between public health objectives and the private industry incentivisation. The evidence in this study raises valid concerns as to whether the granting of additional exclusive rights on medicines is eroding access to medicines for all, favouring profits not connected to the financing of $R \& D$ over social costs.

\section{Recommendations and conclusions}

Based on this research as to the sales revenue of and $R \& D$ investments in a limited number of medicines (sofosbuvir, trastuzumab, and imatinib), it appears that the EU SPC regime may be based on a false premise that companies need longer exclusivity periods to compensate for the 'loss' of a period of effective protection during the market approval process, to enable them to recover $R \& D$ investments. The higher medicines prices associated with the generic competition delays caused by SPCs in relation to the three medicines analysed appears to be an unnecessary cost for society; this cost can be expressed in financial, but also 'social' terms. The SPC system can ultimately cause unnecessary suffering and/ or death, as healthcare systems or patients are unable to afford essential medicines for patients.

The evidence provided in this study suggests a more thorough assessment of the assumptions underpinning the SPC system is required. Acknowledging that the above case studies cover a limited number of medicines, a similar study including more medicines is needed. In view of the current debates on IP incentives in Europe, it is crucial that the Commission provides appropriate evidence on this issue. Moreover, the obstacles to obtaining pharmaceutical companies' actual R\&D cost data further demonstrates the need for greater transparency to enable public scrutiny of healthcare expenditure. This study raises questions as to the public benefit of granting SPCs on medicines altogether, or at minimum calls for fundamental reform to the system and the way SPCs are granted. The conflation of the notions of time and cost in the granting of SPCs appears to be particularly problematic.

\section{Abbreviations}

CE: Copenhagen Economics; CETA: Comprehensive Economic and Trade Agreement; CHF: Swiss franc; CSP: Certificate of Supplementary Protection; DAA: Direct-acting antiviral; ECDC: European Centre for Disease Prevention and Control; ECJ: Court of Justice of European Union; EMA: European Medicines Agency; EPC: European Patent Convention; EPO: European Patent Office; EU: European Union; GDP: Gross Domestic Product; IP: Intellectual Property; MPI: Max Planck Institute; MSF: Médecins Sans Frontières; PrEP: PreExposure Prophylactic; R\&D: Research and Development; SPC: Supplementary Protection Certificate; TDF/FTC: Tenofovir/Emtricitabine; TRIPS: Agreement on Trade-related Intellectual Property Rights; UK: United Kingdom; UN: United

Nations; US: United States; USFDA: United States Food and Drug

Administration; WHO: World Health Organization; WTO: World Trade

Organization

\section{Acknowledgements}

The authors wish to acknowledge the contribution of Christa Cepuch in collecting price information from different EU Member States. The authors wish to acknowledge the contribution of Jacquelyn Veraldi in preparing the manuscript for publication.

\section{Authors' contributions}

HYQ developed the outline, abstract, introduction, review of the evolution of international and national laws on the issue ", and substantively revised the section on the critique on SPC justification. DE developed the case studies on R\&D investments, collected and analysed the pharmaceutical companies' annual financial data, and developed the section on social costs and the prices of medicines in EU member states. PB critically analysed the introduction and justifications of SPC in the EU from a historical legal perspective, and contributed to the international and national review of SPCS and patent term extensions, as well as the general technical review. GK consolidated and restructured the paper in general and contributed to sections on social cost. All the authors read and approved the final manuscript.

\section{Authors' information}

HYQ: Senior Legal and Policy Advisor, MSF Access Campaign, Médecins Sans Frontières; Postdoctoral Research Associate, School of Law, School of Oriental and African Studies (SOAS), University of London

DE: Advocacy Advisor at MSF Access Campaign, Médecins Sans Frontières

PB: Consultant Medicines Law \& Policy

GK: Head of Policy, MSF Access Campaign, Médecins Sans Frontières

\section{Funding}

PB received funding from Médecins Sans Frontières (MSF) to contribute to this research. 


\section{Availability of data and materials}

All data generated or analysed during this study are included in this published article.

\section{Ethics approval and consent to participate} Not applicable.

\section{Consent for publication}

Not applicable.

\section{Competing interests}

The authors declare that they have no competing interests.

\section{Author details}

${ }^{1}$ MSF Access Campaign, Médecins Sans Frontières, Rue de Lausanne 78, P. O Box 1016, CH-1211 Geneva 1, Switzerland. 'School of Law, School of Oriental and African Studies (SOAS), University of London, Russell Square, 10 Thornhaugh Street, Russell Square, London WC1H OXG, UK. ${ }^{3}$ MSF Access Campaign, Médecins Sans Frontières, Rue de Lausanne 78, P. O Box 1016, CH-1211 Geneva 1, Switzerland. ${ }^{4}$ Medicines Law \& Policy, 105 route de Lossiège, 74130 Contamine sur Arve, France. ${ }^{5}$ MSF Access Campaign, Médecins Sans Frontières, Rue de Lausanne 78, P. O Box 1016, CH-1211 Geneva 1, Switzerland.

Received: 16 August 2018 Accepted: 14 November 2019

Published online: 14 January 2020

\section{References}

1. Chabrol F, David P-M, Krikoriand G. Rationing hepatitis C treatment in the context of austerity policies in France and Cameroon: a transnational perspective on the pharmaceuticalization of healthcare systems. Soc Sci Med. 2017;187:243-5 https://doi.org/10.1016/j.socscimed.2017.03.059.

2. World Health Organization. Global report on access to hepatitis $C$ treatment. Geneva: World Health Organization; 2016.

3. European Commission. Joint report on health care and long-term care systems \& fiscal sustainability, volume 1. Brussels: European Commission; 2016.

4. Council of the European Union. Council conclusions on strengthening the balance in the pharmaceutical systems in the EU and its Member States (2016/C 269/06). Luxembourg: OJ C269/31; 2016.

5. European Federation of Pharmaceutical Industries and Associations. EFPIA statement on the Commission's proposal to introduce an SPC manufacturing waiver, weakening Europe's knowledge based economy. 25 May 2018. Available from: https://www.efpia.eu/news-events/the-efpiaview/statements-press-releases/28052018-efpia-statement-on-thecommission-s-proposal-to-introduce-an-spc-manufacturing-waiverweakening-europe-s-knowledge-based-economy/. Accessed 11 Dec 2019

6. Hitchcock J, Tugal B. The latest thinking on best strategies on use of supplementary certificates. Int J Med Mark. 2003;3:220-5.

7. Howard L. Strategic use of supplementary protection certificates. J Generic Med. 2009;6:284-91. https://doi.org/10.1057/jgm.2010.17. Accessed 11 Dec 2019.

8. Whitehead B, Jackson S, Kempner R. Managing generic competition and patent strategies in pharmaceutical industry. J Intellect Property Law Pract. 2008;3:226-35

9. Mazer EH. Supplementary protection certificates in the European economic community. Food Drug Law J. 1993;48:571-6.

10. Medicines for Europe. Supplementary protection certificates: manufacturer waiver - benefits \& myths. Brussels: Medicines for Europe; 2017.

11. European Union. Regulation (EU) 2019/933 amending Regulation (EC) No $469 / 2009$ concerning the supplementary protection certificate for medicinal products. Luxembourg: OJ L153/1; 2019.

12. Collis H. Drug lobby's market protections. Brussels: Politico; 10 May 2017.

13. Médecins Sans Frontières. Open submission on supplementary protection certificates for medicinal products in the European Union. 2017.

14. Max Planck Institute. Study on the legal aspects of supplementary protection certificates in the EU. Luxembourg: European Commission; 2018.

15. Copenhagen Economics. Study of the economic impact of supplementary protection certificates, pharmaceutical incentives and rewards. Luxembourg: European Commission; 2018.
16. Charles Rivers Associates. Assessing economic impact of changing exemption provisions during patent and SPC protection in Europe. Luxembourg: European Commission; 2017.

17. Mejer M. 25 years of SPC protection for medicinal products in Europe: insights and challenges. Luxembourg: European Commission; 2017.

18. Kyle M. Economic analysis of supplementary protection certificates in Europe. Luxembourg: European Commission; 2017.

19. The Council of the European Communities. Regulation (EEC) 1768/92 concerning the creation of a supplementary protection certificate for medicinal products. Luxembourg: OJ L182/1; 1992.

20. May CH, Sell SK. Intellectual property: a critical history. Boulder: Lynne Rienner; 2006.

21. Löfgren $\mathrm{H}$, Williams $\mathrm{O}$. The new political economy of pharmaceuticals: conformity and resistance in the global south. In: Löfgren $\mathrm{H}$, Williams $\mathrm{O}$, editors. The new political economy of pharmaceuticals: production, innovation and TRIPS in the global south. London: Palgrave 2013. p. 1-28.

22. World Trade Organization, Agreement on Trade-Related Aspects of Intellectual Property Rights (TRIPS), 1869 UNTS 299, 33 ILM 1197 (1994). Marrakesh. 1994.

23. Drahos P, Braithwaite J. Hegemony based on knowledge: the role of intellectual property. In: Chen J, Walker G, editors. Balancing act: law, policy and politics in globalisation and global trade. Annandale: Federation Press; 2004. p. 204-23.

24. World Health Organization. Access to medicines. WHO Drug Inf. 2005;19:236-41.

25. United States Congress. Drug Price Competition and Patent Term Restoration Act of 1984, Pub. L. No. 98-417; Washington D.C. 1984.

26. United States Code. Title 35-Patents, Part II, Chapter 14-Issue of Patent, §156 Extension of patent term, 35 USC \$156. United States. 2015.

27. Engelberg A. Special patent provisions for pharmaceuticals: Have they outlived their usefulness? A political legislative and legal history of U.S. law and observations for the future. J Law Technology. 1999;39:389-435.

28. LOI no 90-510 du 25 juin 1990 tendant à rendre identique, pour les médicaments et les autres produits, la durée effective de la protection assurée par les brevets. JORF n¹47 du 27 juin 1990 page 7488.

29. L. 19 ottobre 1991, n. 349. Disposizioni per il rilascio di un certificato complementare di protezione per i medicamenti o i relativi componenti, oggetto di brevetto.

30. Dylst $P$, Vulto A, Simoens S. Overcoming challenges in market access of generic medicines in the European Union. J Generic Med. 2012:9:21-8. https://doi.org/10.1177/1741134312441107. Accessed 11 Dec 2019.

31. El-Said H, El-Said M. TRIPS-plus implications for access to medicines in developing countries: lessons from Jordan-United States free trade agreement. J World Intellect Property. 2007;10:438-75.

32. Akaleephan C, Wibulpolprasert $S$, Sakulbumrungsil R, Luangruangrong $P$, Jitraknathee A, Aeksaengsri A, et al. Extension of market exclusivity and its impact on the accessibility to essential medicines, and drug expense in Thailand: analysis of the effect of TRIPs-plus proposal. Health Policy. 2009;181: 174-82. https://doi.org/10.1016/j.healthpol.2008.12.009. Accessed 11 Dec 2019.

33. Harris T, Nicol D, Gruen N. Pharmaceutical patent review report. Canberra: IP Australia; 2013.

34. European Union. Canada-European Union Comprehensive Economic and Trade Agreement Implementation Act. Luxembourg: OJ L11/23; 2017.

35. Bagnoli P, Busbyl C. Patent restoration and the cost of pharmaceuticals. Ottawa: Office of the Parliamentary Budgetary Officers of Canada; 2018.

36. European Union. Regulation (EC) 469/2009 concerning the supplementary protection certificate for medicinal products. Luxembourg: OJ L152/1; 2009.

37. Grabowski HG, Vernon JM. Effective patent life in pharmaceuticals. Int J Technol Manag. 2000;19:98-120. https://doi.org/10.1504/IJTM.2000.002803. Accessed 11 Dec 2019

38. European Parliament. Resolution on EU options for improving access to medicines (2016/2057(INI)), 2017.

39. Ricciardi W, Barros PP, Bourek A, Brouwer W, Lehtonen L, McKee M, et al. Innovative payment models for high-cost innovative medicines - Report of the Expert Panel on effective ways of investing in Health. Luxembourg: European Commission; 2018.

40. de Jongh T, Radauer A, Bostyn S, Poort J. Effects of supplementary protection mechanisms for pharmaceutical products. Amsterdam: Technopolis Group; 2018.

41. European Commission. Impact assessment - Proposal for a Regulation of the European Parliament and of the Council amending Regulation (EC) No $469 / 2009$ concerning the supplementary protection certificate for medicinal products. SWD (2018) 240 final. Brussels: European Commission; 2018. 
42. Harris R. R\&D Costs For Cancer Drugs Are Likely Much Less Than Industry Claims, Study Finds: Washington: NPR; 2017.

43. Médecins Sans Frontières. Lives on the Edge: Time to align medical research and development with people's health needs. 2016.

44. Prasad V, Mailankody S. Research and Development spending to bring a single Cancer drug to market and revenues after approval. JAMA Intern Med. 2017;177:1569-75.

45. Adams C, Brantner V. Estimating The Cost Of New Drug Development: Is it Really $\$ 802$ Million? Health Affairs Market Watch. 2006;25. https://doi.org/1 0.1377/hlthaff.25.2.420. Accessed 11 Dec 2019.

46. DiMasi J, Grabowski H, Hansenc R. Innovation in the pharmaceutical industry: new estimates of R\&D costs. J Health Econ. 2016;47:20-33. https:// doi.org/10.1016/j.jhealeco.2016.01.012. Accessed 11 Dec 2019.

47. Gilead. Fourth quarter and full year financial results 2004-2017. Available from: https:/www.gilead.com/news/press-releases/ . Accessed 11 Dec 2019.

48. Roche. Financial reports 2004-2017. Available from: https://www.roche. com/investors/downloads.htm . Accessed 11 Dec 2019.

49. Novartis. Annual reports 2004-2017. Available from: https://www.novartis. com/investors/novartis-annual-reporting-suite/annual-report-and-20-farchive\#ui-id-3=1. Accessed 11 Dec 2019.

50. Morris C. America's most expensive prescription drugs. New Jersey: CNBC; 2017.

51. Krauskopf $L$, Basu A. Gilead bets $\$ 11$ billion on hepatitis in Pharmasset deal. New York: Reuters; 2011.

52. Gilead. Press Release: U.S. Food and Drug Administration approves Gilead's Sovaldi ${ }^{\text {TM }}$ (Sofosbuvir) for the treatment of chronic hepatitis C. 6 December 2013. Available from: https:/www.gilead.com/news-and-press/press-room/ press-releases/2013/12/us-food-and-drug-administration-approves-gileadssovaldi-sofosbuvir-for-the-treatment-of-chronic-hepatitis-c . Accessed 11 Dec 2019.

53. Sovaldi (sofosbuvir). An overview of Sovaldi and why it is authorised in the EU. London: European Medicines Agency; 2019.

54. European Patent Register, EP2203462 (Gilead. Nucleoside phosphoramidate prodrugs). Munich. 2014. https://register.epo.org/application?number= EP08732818\&lng=en\&tab=main. Accessed 11 Dec 2019.

55. European Patent Register, EP2604620 (Gilead. Modified fluorinated nucleoside analogues). Munich. 2016. https://register.epo.org/ application?number=EP13152340. Accessed 11 Dec 2019.

56. National Industrial Property Institute of France, Supplementary Protection Certificate FR14C0082. https://bases-brevets.inpi.fr/en/document-en/FR14 C0082.html?p=5\&s=1576078625187\&cHash=1775515fafe3642917f44bedbd6 dc29e. Accessed 11 Dec 2019.

57. Swedish Patent Database, Supplementary Protection Certificate SE 14900666. https://was.prv.se/spd/search?tab=4\&lang=en. Accessed 11 Dec 2019.

58. The State Patent Bureau of the Republic of Lithuania, Supplementary Protection Certificate C2203462/PA2014040. https://www.vpb.lt/db_eu_patentai/ papildoma_apsauga.php?db=vpb_europat\&idappli=X1250046\&extidpatent_ old=2203462\&extidappli_pagr=08732818.3\&id=. Accessed 11 Dec 2019.

59. Industrial Property Office of the Slovak Republic, Supplementary Protection Certificate PDO5029-2014. https://wbr.indprop.gov.sk/WebRegistre/ DodatkoveOchranneOsvedcenie/Detail/5029-2014. Accessed 11 Dec 2019.

60. Vasella D. Magic cancer bullet: how a tiny orange pill is rewriting medical history. Harper Collins: New York; 2003.

61. Jones GH, Carrier MA, Silver RT, Kantarjian H. Strategies that delay or prevent the timely availability of affordable generic drugs in the United States. Blood. 2016;127:1398-402. https://doi.org/10.1182/blood-2015-11-6 80058. Accessed 11 Dec 2019.

62. European Patent Register, EP0564409 (Novartis. Pyrimidin derivatives and process of their preparation). Munich. 2000. https:/register.epo.org/ application?number=EP93810219\&tab=main. Accessed 11 Dec 2019

63. Oosting B, van den Bos H. The Hague court confirms paediatric extension of SPC for former EU orphan drug imatinib: Lexology 2016. Available from: https://www.lexology.com/library/detail.aspx?g=c45e5f48-de26-46f6-afc88c13c2eabb63. Accessed 11 Dec 2019.

64. National Industrial Property Institute of France, Supplementary Protection Certificate FRO2C0012 (Novartis. Imatinib mesilate). France. 2014. https:// bases-brevets.inpi.fr/en/document-en/FR02C0012.html?p=5\&s=1576080671 877\&cHash=9608a45d568e01d4bbcefd69ae640561. Accessed 11 Dec 2019.

65. Genentech. Press Release: Roche and Genentech sign licensing agreement for Herceptin. 1998. Available from: https://www.gene.com/media/pressreleases/4778/1998-07-06/roche-and-genentech-sign-licensing-agree. Accessed 11 Dec 2019
66. Genentech. Press Release: 2nd Quarter Results. 1998. Available from: https:// www.gene.com/media/press-releases/4777/1998-07-14/genentech-reports-1 998-2nd-quarter-resul. Accessed 11 Dec 2019.

67. Roche. Annual report: KU Leuven Library; 1999. Available from: https://bib. kuleuven.be/files/ebib/jaarverslagen/ROCHE_1999.pdf. Accessed 11 Dec 2019.

68. OFX. Yearly average exchange rates 2019. Available from: https://www.ofx. com/en-au/forex-news/historical-exchange-rates/yearly-average-rates/.

69. European Patent Register, EP0590058 (Genentech, Humanized heregulin antibody). Munich. 2004. https://register.epo.org/application?number=EP92 914220\&tab=main. Accessed 11 Dec 2019.

70. Swiss Federation Institute of Intellectual Property, Supplementary Protection Certificate, C00590058/01 (Genentech, Humanized heregulin antibody). Bern. 2005. https://www.swissreg.ch/srclient/en/spc/C00590058/01. Accessed 11 Dec 2019.

71. The National Industrial Property of France (INPI), CCP de médicament (SPC), FR04C0007 (Genentech, Humanized heregulin antibody). Paris. 2010. https:// bases-brevets.inpi.fr/en/document-en/FR04C0007.html. Accessed 11 Dec 2019

72. Intellectual Property Office of the United Kingdom, Supplementary Protection Certificate, SPC/GB04/015 (Genentech, Humanized heregulin antibody). UK. Newport.2012. https://www.ipo.gov.uk/p-find-spc-bypatentresults.htm?number=EP0590058. Accessed 11 Dec 2019.

73. Pollack A. Roche agrees to buy Genentech for $\$ 46.8$ billion. New York: New York Times; 2009.

74. Human Rights Council. Resolution: Access to Medicines in the Context of the Right of Everyone to the Highest Attainable Standard of Physical and Mental Health. A/HRC/RES/12/24. 2009.

75. United Nations. Report of the United Nations secretary-General's high-level panel on access to medicines. 2016.

76. World Health Organization. Medicines shortages: global approaches to addressing shortages of essential medicines in health systems. Drug Inf. 2016;30:181-5.

77. Hirschler B. How drugmakers face global push back on high prices. New York: Reuters; 2017.

78. Iyengar $\mathrm{S}$, Tay-Teo $\mathrm{K}$, Vogler $\mathrm{S}$, Beyer $\mathrm{P}$, Wiktor $\mathrm{S}$, de Joncheere $\mathrm{K}$, et al. Prices, costs, and affordability of new medicines for hepatitis $C$ in 30 countries: an economic analysis. PLoS Med. 2016;13:e1002032. https://doi. org/10.1371/journal.pmed.1002032. Accessed 11 Dec 2019.

79. Mouterde AL, Bocquet F, Fusier I, Paubel P. Hepatitis C: how has France limited the expenses related to new treatments? Expert Rev Pharmacoecon Outcomes Res. 2016;16:655-7. https://doi.org/10.1080/14737167.2016. 1247696. Accessed 11 Dec 2019.

80. Inspection Générale des Affaires Sociales. Rapport: Evaluation medicoéconomique en santé 2014 No 2014-066R.

81. Ministère de la Solidarité et de la Santé. Commmuniqué - Accès universel aux traitements contre l'hépatite C: Marisol Touraine obtient une baisse de prix significative. 2016. Available from: https://solidarites-sante.gouv.fr/ archives/archives-presse/archives-communiques-de-presse/article/accesuniversel-aux-traitements-contre---hepatite-c-marisol-touraine-obtient. Accessed 11 Dec 2019

82. Le Figaro. Un médicament efficace contre l'hépatite $C$ vient d'être autorisé à la vente en pharmacie. Paris: Le Figaro; 2018.

83. Hépatite C. Les médicaments de Gilead bientôt disponibles en pharmacie. Paris: BFMTV; 2018

84. Preda CM, Popescu CP, Baicus C, Voiosu TA, Manuc M, Pop CS, et al. Realworld efficacy and safety of ombitasvir, paritaprevir/ $r+$ dasabuvir+ribavirin in genotype 1b patients with hepatitis C virus cirrhosis. Liver Int. 2018;38:60210. https://doi.org/10.1111/liv.13550. Accessed 11 Dec 2019.

85. Bocci M. Via libera all'acquisto dei generici all'estero. Rome: la Repubblica; 2017.

86. Cullen $\mathrm{P}$. Hepatitis $\mathrm{C}$ patients unable to get drugs due to funding problems. Dublin: Irish Times; 2017.

87. Patent Opposition Database. Available from: https://www.patentoppositions. org/en/drugs/sofosbuvir. Accessed 11 Dec 2019.

88. Médecins Sans Frontières. Press Release: MSF secures lower price for generic hepatitis C treatment. Geneva; 2017. Available from: https:/www.msf.org/msfsecures-lower-price-generic-hepatitis-c-treatment. Accessed 11 Dec 2019.

89. Médecins Sans Frontières. Press release: Appeal lodged against decision to uphold Gilead's patent on hepatitis C drug. Paris; 2018. Available from: https://www.msf.org/appeal-lodged-against-decision-uphold-gileads-patenthepatitis-c-drug. Accessed 11 Dec 2019. 
90. World Health Organization. WHO implementation tool for pre-exposure prophylaxes (PrEP) of HIV infection. Geneva: Module 6: Pharmacists; 2017.

91. World Intellectual Property Organization, Patentscope, WO9905150 (Gilead. Nucleotide analog composition and synthesis method). Geneva. 1999. https://patentscope.wipo.int/search/en/detail.jsf?docld=WO1999005150\&_ cid=P11-K41HSV-36659-1. Accessed 11 Dec 2019.

92. World Intellectual Property Organization, Patentscope, WO9111186 (Gilead Method and compositions for the synthesis of Bch-189 and related compounds). Geneva.1991. https://patentscope.wipo.int/search/en/detail. jsf?docld=WO1991011186\&_cid=P11-K41HW3-37409-1. Accessed 11 Dec 2019.

93. Pelé S, Thill-Tayara M, Schaffner M, Mitouard S, Devinant C. Combination of active ingredients - scope of protection - Gilead: Lexology; 2018. Available from: https://www.lexology.com/library/detail.aspx?g=dba23973-b2d2-49498e79-4b73415d8a55. Accessed 11 Dec 2019.

94. Biogaran v Gilead. RG 17/09565: Paris Court of First Instance; 2018

95. The SPC Blog. France - Paris Court of First Instance nullifies Truvada SPC. 2018. Available from: http://thespcblog.blogspot.com/2018/05/france-pariscourt-of-first-instance.html. Accessed 11 Dec 2019.

96. The SPC Blog. Germany - Gilead's SPC for Truvada nullified by the Federal Patent Court. 2018. Available from: http://thespcblog.blogspot.com/2018/ 05/germany-gileads-spc-for-truvada.html. Accessed 11 Dec 2019.

97. Leavitt A, Lynch J. Gilead versus generics in Ireland - summary of case and observations from court. Dublin: Act-Up Dublin; 2017.

98. Paul M. Gilead loss of generic HIV drug battle a boost for gay community. Dublin: Irish Times; 2017.

99. The SPC Blog. Denmark - Gilead successfully enforces its SPC for Truvada. 2018. Available from: http://thespcblog.blogspot.com/2018/03/denmarkgilead-successfully-enforces.html. Accessed 11 Dec 2019.

100. Mepha Pharma AG vs. Gilead. O2017_001: Swiss Federal Patent Court; 2017.

101. The SPC Blog. Switzerland - Truvada and moving away from the "infringement test" for future SPCs for combination products. 2018. Available from: http://thespcblog.blogspot.com/2018/06/switzerlandtruvada-and-moving-away.html. Accessed 11 Dec 2019.

102. Gilead vs. Mylan. C/17/00048: Brussels Court of Commerce; 2017.

103. Teva and others vs. Gilead. [2017] EWHC 13 (Pat): England and Wales High Court (Patent Court); 2017.

104. Boulet P. CJEU ruling on Truvada recalls 'evergreening' goes against public health interests: Mediccines law \& Policy 2018. Available from: https:// medicineslawandpolicy.org/2018/09/cjeu-ruling-on-truvada-recallsevergreening-goes-against-public-health-interests/. Accessed 11 Dec 2019.

105. European Centre for Disease Prevention and Control. Evidence brief: Preexposure prophylaxis for HIV prevention in Europe. Stockholm: ECDC; 2016.

106. Teva vs. Gilead. C-121-17: Court of Justice of the European Union; 2018.

107. Medicijnkosten. Zorgintituut Nederland. Available from: https://www. medicijnkosten.nl.

108. Vergoedbare geneesmiddelen. Riziv. Available from: http://ondpanon.riziv. fgov.be/SSPWebApplicationPublic/nl/Public/ProductSearch.

109. British National Formulary. Medicines Complete, The Royal Pharmaceutical Society. Available from: https://about.medicinescomplete.com/\#/content/ bnf/_180330626?hspl=truvada\#DMD9098011000001105.

110. Danish Medicines Agency. Database Medicinpriser.dk. Available from: https://medicinpriser.dk/default.aspx.

111. Legemiddelsøk. Norwegian Medicines Agency. Available from: https://www. legemiddelsok.no.

112. Fiche de presentation Truvada. Ministère des Affaires Sociales et de la Santé. Available from: http://medicprix.sante.gouv.fr/medicprix/detailPresentation. do? parameter $=$ afficherPresDetail\&idPresentation $=49800$.

113. ABDATA: Pharma-Daten-Service. Mediengruppe Deutscher Apotheker. Available from: http://abdata.de/datenangebot/abda-datenbank/.

114. Arzneimitteldatenbank. Arznei-telegramm ${ }^{\oplus}$. Available from: https://www. arznei-telegramm.de/01atd_info1.php3.

115. Medikamentensuche. Mymedi.ch. Available from: https://www.mymedi.ch/.

116. IPU product file. Irish Pharmacy Union. Dublin. Available from: https://ipu.ie/ home/ipu-product-file/.

117. Pharmaceutisch Weekblad. PrEP verkrijgbaar voor $€ 50$ per maand. Den Haag: PW04; 2018.

118. Wilson C. Massive drop in London HIV rates may be due to internet drugs. London: New Scientist; 2018.

119. La PrEP: AIDES; 2018. Available from: https://www.aides.org/prep. Accessed 11 Dec 2019.
120. PrEP will soon be available for 50 Euros in Germany, starting in seven cities Berlin: Deutsche Aidshilfe; 2017. Available from: https://www.aidshilfe.de/ meldung/prep-will-soon-available-50-euros-germany-starting-seven-cities. Accessed 11 Dec 2019.

121. Halpin H. A HIV prevention drug is being made available to Irish pharmacies at a 70\% cheaper cost. Dublin: TheJournal.ie; 2017.

122. Hiv-preventiepil PrEP na jarenlange lobby in Nederland vergoed, Aidsfonds mist urgentie bij minister Amsterdam: AT5; 10 juli 2018. Available from: http://www.at5.nl/artikelen/184165/hiv-preventiepil-prep-na-jarenlangelobby-in-nederland-vergoed-aidsfonds-mist-urgentie-bij-minister. Accessed 11 Dec 2019.

123. Geneesmiddel in PrEp om een HIV-infectie te voorkomen: terugbetaling vanaf 1 juni 2017: Riziv; 2017. Available from: http://www.inami.fgov.be/nl/ themas/kost-terugbetaling/door-ziekenfonds/geneesmiddelgezondheidsproduct/terugbetalen/specialiteiten/wijzigingen/Paginas/ geneesmiddelen-PrEp-HIV.aspx\#.W0jMyGePXXo. Accessed 11 Dec 2019.

124. PrEP on the NHS London: I want PrEP now. Available from: https://www. iwantprepnow.co.uk/prep-on-the-nhs. Accessed 11 Dec 2019

125. Collis H. England's HIV prevention trial to test generic Truvada. Brussels: Politico; 2017.

126. Duffy N. Norway to provide free HIV-preventing PrEP drugs to at-risk gay men. London: Pink News; 2016.

127. Schwinn M. HIV-prophylaxe soll krankenkassenleistung werden. Munich: Süddeutsche Zeitung; 2018.

128. PrEP Zürich: Aide Suisse Contre le Sida. Available from: https://www.aids.ch/ en/faq/protection-risk/prep.php. Accessed 11 Dec 2019.

129. Finnegan B. More affordable PrEP to be made available in Irish pharmacies. Dublin: GCN; 2017

130. XE. Available from: www.xe.com

131. Coleman R, Prins M. Options for affordable pre-exposure prophylaxis (PrEP) in national HIV prevention programmes in Europe. Euro Surveill. 2017;22. https:// doi.org/10.2807/1560-7917.ES.2017.22.42.17-00698. Accessed 11 Dec 2019.

132. Butterworth B. Europe's largest sexual health clinic launches PrEP service due to huge demand. London: Pink News; 2018.

133. Neves $V$. The theory of social costs of K. William Kapp: some notes on Sebastian Berger's the social costs of neoliberalism. Forum Soc Econ. 2018:1-13. https:// doi.org/10.1080/07360932.2018.1481127. Accessed 11 Dec 2019.

134. Choe S-C, Kim W. Globalization and Urbanization in the Republic of Korea. In: Yusuf S, Evenett S, Wu W, editors. Facets of Globalization International and Local Dimensions of Development: World Bank Paper n415; 2001.

135. Bridy A. Trade secret prices and high-tech devices: how medical device manufacturers are seeking to sustain profits by Propertizing prices. Tex Intell Prop LJ. 2009;17:187-222.

\section{Publisher's Note}

Springer Nature remains neutral with regard to jurisdictional claims in published maps and institutional affiliations.

Ready to submit your research? Choose BMC and benefit from:

- fast, convenient online submission

- thorough peer review by experienced researchers in your field

- rapid publication on acceptance

- support for research data, including large and complex data types

- gold Open Access which fosters wider collaboration and increased citations

- maximum visibility for your research: over $100 \mathrm{M}$ website views per year

At $\mathrm{BMC}$, research is always in progress.

Learn more biomedcentral.com/submissions 